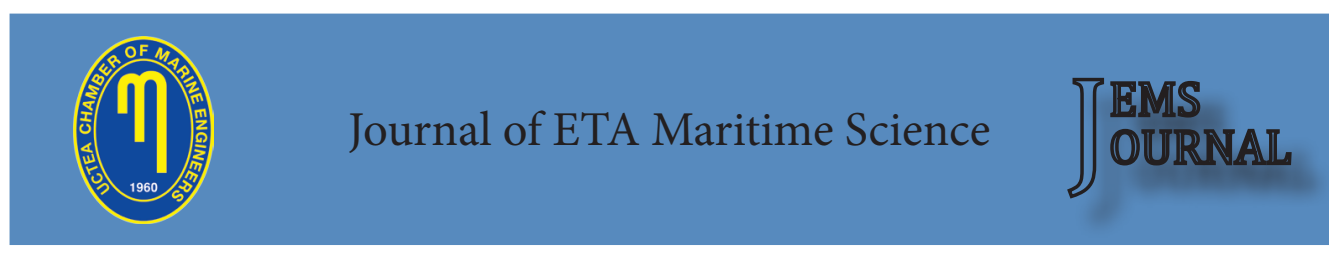

\title{
Container Port Selection in Contestable Hinterlands
}

\author{
Kemal AKBAYIRLI ${ }^{1,2}$, Durmuş Ali DEVECI'², Gökçay BALCI ${ }^{2,3}$, Ercan KURTULUŞ ${ }^{4}$ \\ ${ }^{1}$ Ordu University, Fatsa Faculty of Marine Sciences, kemal.akbayirli@gmail.com \\ ${ }^{2}$ Dokuz Eylül University, Maritime Faculty, adeveci@deu.edu.tr \\ ${ }^{3}$ Bursa Technical University, Faculty of Maritime Studies, gokcay.balci@deu.edu.tr \\ ${ }^{4}$ Karadeniz Technical University Sürmene Faculty of Marine Sciences, kurtulusercan@yahoo.com
}

\begin{abstract}
Port competition has become fiercer with each passing day due to the developments in hinterland networks, port innovations at ports, port privatization policies and the changing specific service expectations of port users. This competitive environment has led to shifting the hinterland areas from captivity to contestability. The customer focus in determining the level of service quality and service diversity is crucial to gain a share from such contestable and competitive hinterlands. Therefore, the main aim of this study is to determine port selection criteria of port users and to develop a model for measuring selection criteria of port users in contestable hinterlands. A confirmatory factor analysis was applied to develop a model for port selection in a contestable hinterland. The model includes 7 main constructs and total 32 criteria. The model reveals that competitiveness of ports in contestable hinterlands is not only affected by ports' own services but external ones such as number and frequency of shipping lines calling at the port are also vital.
\end{abstract}

Keywords: : Container Port, Competitiveness, Port Selection, Contestable Hinterland.

\section{Rekabete Açık Hinterlantlarda Konteyner Limanı Seçimi}

$\ddot{O} \mathbf{z}$

Gelișen hinterlant bağlantıları, liman inovasyonları, liman özelleştirme politikaları ve liman kullanıcılarının değișen özel beklentileri nedeniyle liman rekabeti her geçen gün daha çetin bir hal almaktadır. Bu rekabetçi ortam liman hinterlantlarının kazanılmış olmaktan çıkıp rekabete açık olmalarına yol açmışıtır. Bu rekabete açık ve rekabetçi hinterlantlardan pay almak için hizmet kalitesinin düzeyinin ve servis çeşitliliğinin belirlenmesinde müşteri odakl olmak elzemdir. Bu nedenle, bu çalışmanın amacı, rekabete açık hinterlantlardaki liman kullanıcılarının liman seçim kriterlerini araştırmak ve bu liman kullanıcılarının seçim kriterlerini ölçen bir model geliştirmektir. Rekabete açık hinterlantlarda liman seçimine ilişkin bir model geliştirmek için doğrulayıcı faktör analizi uygulanmıştır. Model 7 ana çatı ve toplam 32 kriterden oluşmaktadır. Model, rekabete açık 
alanlarda limanların rekabetçiliğinin sadece hizmet tabanlı etmenlerden etkilenmediğini ayrıca, limana uğrakyapan hatların sayısı ve sıklığı gibi dış faktörlerin de oldukça önemli olduğunu ortaya koymaktadır.

Anahtar Kelimeler: Konteyner Limanı, Rekabetçilik, Liman Seçimi, Rekabete Açık Hinterlant.

\section{Introduction}

The role of ports has been getting more important in logistics system where ports create significant value for their users [1]. Containerization has also made the ports an important part of the supply chain systems as well as integrated with distribution centers in the hinterlands. The increasing global trade has triggered the demand for container-based shipments. Moreover, development of transshipment container handling due to rising hub and spoke systems has significantly increased the number of containers handled at ports [2].

In parallel with rapidly increasing demand for container handling at ports, competition between ports has also became fiercer to gain more share from the growing pie of container transportation. One of the important factors that trigger competition between container ports is the participation of private firms in port business which has increased significantly through privatization practices of governments in recent years [3]. Expectations of global shippers increasing with their requirements for improving own supply chain systems also affect the competition between ports. Besides, thanks to improvement in land transport connections and the increasing number of container terminals in different regions, captive hinterlands are becoming contestable. In contestable hinterlands, port users have different port alternatives to choose between them [4]. Ports strive for gaining more shares not only from transshipment containers but also from contestable hinterlands.

Port industry has been rapidly increasing and becoming more competitive in Turkey as well, thanks to developing foreign trade and privatization of ports. In such a competitive environment, ports need to understand needs and requirements of port users to improve their services. As ports have started to compete with each other in contestable hinterlands, understanding port selection criteria of port users in contestable hinterlands is essential for them. Thus, the purpose of this study is to investigate port selection criteria of port users at a contestable hinterland. A survey study is conducted with freight forwarders who operate with shippers located in Ankara-Eskişehir-Kütahya region. This region is considered to be quite contestable in terms of port competition. Port users in this region may prefer to work with the container terminals located in Marmara Region, in İzmir and Mersin. The competition has become even fiercer recently due to the privatization of Mersin, Derince and Bandırma Ports and newly built private container terminals both in İzmir and Marmara regions. Thus, investigating the selection criteria of port users in this region can help selection criteria of port users in contestable hinterlands.

In other respect, most of the existing port selection literature are carrier and shipperfocused. However, nowadays, shippers steer their transportation activities to freight forwarding, and therefore a clear and exact research, reflecting freight forwarders' considerations about port selection must be revealed with this study. Our study contributes to the port competition literature in two ways. First, the number of port selection studies with only from freight forwarders' viewpoint is limited in the literature [5]. However, nowadays shippers authorize freight forwarders to handle their transportation operations. Therefore, 
a study reflecting freight forwarders' considerations about port selection is needed in the literature. Second, very few studies considering port competition in contestable hinterland perspective exist [4]. To the knowledge of authors, no study has investigated port competition in contestable hinterland perspective in Turkey. Thus, our study also enriches the port competition literature in this context. In the following sections of the study, port competition and hinterland concepts are discussed, and then in port selection part, results of several studies on port selection are touched upon. In light of these studies, some factors are classified into groups, which are tested via confirmatory factor analysis. In methodology and discussion parts these items will profoundly be defined.

\section{Literature Review}

\subsection{Concept of Port Competition}

Traditionally, competition can be defined as striving to gain what other actors to gain at the same time. After 1980's the more liberalized transportation industry, acceleration of containerized cargoes, and the enhancement in shipping activities has strikingly led world ports to compete with each other $[6,4]$. The growing ship size and mass transportation in a single shipment have caused to diminish the number of the ships that is called on; hence causing intensive port competition and emerging significance of transshipment in determining the competitive position of ports [7]. Moreover, for port competitiveness in modern-day port services are needed to be integrated into global supply chain $[6,4]$. These logistics integration have forced the ports to reconsider their function in freight distribution stream and the expanding competition within the hinterland [8]. Because ports are now contestable market with a series of competing ports and shipping intermediaries [6] governments can support competitive environment when the risk of monopoly occur. Even though profitability is an important factor in existing competition [9], port competition is no longer only cost oriented. Furthermore, faster, qualified, efficient and cost-effective services are needed [6]. The competitive strength of ports is basically determined by the element of production such as labor, capital, technology, and energy. On the other hand competition between ports is also influenced by location, infrastructure, level of industrialization, port performance and government policy [10].

Competitiveness factor of a port is directly related to its technical and cost efficiency and throughput level. The size of port traffic is also important in terms of market share, diversification, and development [11]. After all, not only port location and port tariffs are important but also the terms efficiency, reliability, quality of infrastructure, variety of port services, frequency of shipping services, and integration to routes have became in question in competition [6].

The supply chain accession is a key indicator for a port, therefore efficient linkage of a port to the port hinterland yields the requirements of shippers and suppliers by providing cost, time and availability advantage in freight flow [12]. Since container ports have begun to link global logistics chain, competition between ports has shifted to competition between transport chains [1]. Although the capacity of hinterland transportation does not completely match the cargo volume of its port; hinterland access is still assumed as the initial success factor of a port $[13,14]$.

Port business in Turkey has been witnessing dramatic developments in recent years. The number of containers handled at ports in Turkey has significantly increased in last 10 years. The development is quite obvious that the total number of containers handled increased from 2.492.750 in 2003 to 6.721 .767 in 2015. The port industry has also became more competitive in Turkey thanks to privatization activities of government for ports, newly built container 
terminals by private enterprises, especially by global port operators.

\subsection{Port Hinterland Concept}

The scope of terminal traffic is straightly associated with the market they serve [15]. This geographical and spatial marketplace is the range of the land area where a port serves, traditionally called as hinterland [6]. Port specifications, particularly its location, formalize hinterlands [15]. Hinterlands are areas sited at the rear of terminals deliver and promote cargoes, export movements, and transport and appeal imports [16]. Cargo movement is either from main hinterland or competition margin. The port is a principal in the main hinterland while the port competes with others in competition margin. The main hinterland is the heart of the market of a port with advantageous access level [17].

Hinterlands consist of three main sub-categories; the macroeconomic, the physical and logistical hinterland. The macroeconomic hinterland identifies the elements which have impact on transport demand, and it mainly focuses on production and consumption level; the physical hinterland considers nature and dimensions of transport supply [17], and it is also a substance of this cluster from intermodal and modal view, therefore transportation network are supposed as the basic tool for connection hinterland thereby providing regional accessibility [15]; and logistical hinterland is related with organization of supply and demand [17].

There are several studies on port hinterlands in the literature [4]. The latest studies show that distribution stream brings about captive hinterlands while most ports extremely compete for contestable container markets [14]. The shift from captive to contestable hinterland switches the condition of the port market from monopolistic or oligopolistic to competitive [18]. An absolute difference between captive and contestable hinterlands is that the captive hinterland represents the regions in which one port has a competitive advantage by virtue of lower transport cost, and this port undertakes the majority of cargoes from these regions. The captive hinterland is where a port has higher impact and share on the cargo flow within a portion of the potential market that is nearer to the terminal [16]. The captive hinterlands do not face direct competition [19].

The contestable market theory facilitates entry and exit to markets with growing efficiency, in spite of a limited number of firms exist in the sector, the prices of products or services change competition margin. Therefore in the perfect contestable market, potential entrants threat the incumbent companies to act competitively [20].

There are three main parameters influencing port hinterland; location, accessibility and infrastructure [16]. The location is the starting point of port development. The port system development models indicate a switch from weakly connected terminals to a main network of corridors between ports and major hinterland [21]. The accessibility has three wide approaches; infrastructure-based accessibility, activity-based accessibility, and utility-based accessibility [22]. Even so, accessibility of a hinterland is a key part of port competition; intermodal corridors diminish bottlenecks between the port and its hinterland and improve accessibility. As a result of accessibility conditions, the hinterlands have switched from captive to contestable where main hubs struggle for giving weight to efficient hinterland network [23, 24, 25].

\subsection{Container Port Selection Criteria of Port Users}

Ports serve in a competitive environment thereby meeting customers' needs for enhancing market share and the attributes of port services attract customers on their decision [26]. In order to retain 
their market, ports should maintain their performance and should clearly understand and determine the port users' requirements for affecting the decision of users [27]. The determinants of port choice have severally been studied [28]. There are many criteria that have been found in early research on the port selection of shippers, forwarders and shipping companies. For instance, Saeed and Aaby [26] used following attributes to examine the selection criteria for ports: service quality, loading/discharging rate, handling charges, number of TEU handled at the port, number of vessels calling at the port, level of congestion at the port, location, efficiency of the hinterland connections, personal contacts, logistical services provided at the port, storage facilities, value-added services provided at the port, navigational availability (night navigation), switching cost from one port to another, asset specification, structure of port authorities and ownership.

According to Talley [11] price and characteristics of ports and ship schedule characteristics of ships calling at a port are major influencers in port selection. Port and ship schedule characteristics affect shipper who is exposed to cost of time.

Bichou [6] also classifies the selection criteria into three main groups, and each category has its own sub-factors; route factors (location, accessibility, connectivity, hinterland network, frequency and transit time), cost factors (freight rates, tariff and charges and capacity) and service factors (several aspects such as efficiency congestion, reliability, flexibility, safety and security). However, authors [28] strongly highlight that tariff and service characteristics of road and rail companies, the frequency of ship visits, and freight rates are important issues in port selection. Besides, the port choice decision of shippers and forwarders is directly and indirectly influenced by carriers' port selection. In compliance with several studies on shipping lines' port selection criteria, Overall berth side efficiency, cost, total demand for the terminal [29], dynamics on trade route, regional market level of hinterland [30], loading/discharging rate, handling charges, service quality [26] are initial influencer for shipping lines' port selection. Along with cost and service-related factors, shippers' location, marketing strategies of shipping line (new entry, penetration etc.), and arrangements between carrier and port operator [31] are found as the other factors affecting carriers' decision. However, these studies also show that a shipping line's selection factors directly concern with shippers and freight forwarders' decisions likewise. On the other hand, because carriers play an active role in efficiency level of supply chain they are closely interested in supply chain integration and the efficiency of land operations.[29, 30,31].

Most of the studies related to port competitiveness suggested facility and equipment, port charges, transit time, the frequency of travel and damage on cargo, hinterland connectivity, potential market location and hinterland, and port accessibility as vital port competitiveness criteria in the 1980s. On the other hand at the next decade, although more comprehensive perspectives were in question such as politic, social, stability, geographical location and quantity of throughput etc., service quality, transit time, equipment ability and cargo information are the major factors of port choice in much analysis. The analysis results of 2000s' studies show that the criteria such as location and economy capacity of the hinterland have been given more attentions than before [32].

\section{Methodology}

The primary data collection method of this study is questionnaire survey. In order to determine the variables used in the questionnaire, relevant literature on port selection criteria was reviewed. The port selection literature, especially port selection by shippers and forwarders were taken into consideration in the questionnaire development. Out of 24 
Table 1. Grouping of Variables under Main Port Selection

\begin{tabular}{|c|c|}
\hline Main Port Selection Criteria & Port Selection Variables \\
\hline \multirow{3}{*}{$\begin{array}{l}\text { Port Location and Hinterland } \\
\text { Connections }\end{array}$} & Port-Road Connection \\
\hline & Port-Railway Connection \\
\hline & Distance of Port to Cargo Origin and Destination \\
\hline \multirow{5}{*}{$\begin{array}{l}\text { Port Physical and Technical } \\
\text { Infrastructure and Superstructure }\end{array}$} & Size of Port Warehousing Area \\
\hline & Information Technologies Used at Port \\
\hline & Number of Port Equipment \\
\hline & Quality and Technology of Port Equipment \\
\hline & Reefer Cargo Warehousing Capacity of Port \\
\hline \multirow{2}{*}{ Port Management and Administration } & Port Management Type \\
\hline & Feature of Port Operating Company \\
\hline \multirow{13}{*}{ Port Service Quality } & Value-added Services offered at Port \\
\hline & Reliability of Services offered by Port \\
\hline & Corporate Social Responsibility of Port \\
\hline & Green Port Applications of Port \\
\hline & Logistics Services provided by Port \\
\hline & Flexibility of Port for Specific Requirement of Customers \\
\hline & Customized Services \\
\hline & Informing Shippers about Shipment \\
\hline & Performance of Port About Cargo Loss and Damage \\
\hline & Safety of Port \\
\hline & Quick Response to Users Problem \\
\hline & Attitude and Behavior of Port Personnel \\
\hline & Experience and Ability and Competence of Port Personnel \\
\hline \multirow{2}{*}{ Port Efficiency and Productivity } & Congestion at Port \\
\hline & Total Turnaround Time \\
\hline \multirow{4}{*}{ Port Tariff and Costs } & Total Port Tariff and Cost \\
\hline & Flexibility of Port in Pricing \\
\hline & Ease of Payment for Customers \\
\hline & Total Logistics Cost incurred due to Port Choice \\
\hline \multirow{3}{*}{$\begin{array}{l}\text { Number and Frequency of Shipping } \\
\text { Lines Calling at Port }\end{array}$} & Number of Container Lines Calling the Port \\
\hline & Frequency of Sailings \\
\hline & Total Transit Time for Cargo \\
\hline
\end{tabular}

researches on port selection criteria, it was found that 16 of them are related to either shipper, forwarder or both perspectives. The variables used by forwarders for measuring port selection by forwarders were discussed with 5 experienced freight forwarders through interviews in terms of their clarity and appropriateness of their content. The interviews helped the researcher to ensure face validity of the scale. Necessary adjustments and corrections were made in the questionnaire according to views and comments of freight forwarders and academicians.

The variables used for port selection with shippers and forwarders perspectives were found to be concentrated under 7 main constructs. These 7 main constructs 
include totally 35 variables. These constructs and variables are taken from literature according to their adaptability to the Turkish port competition, and they have been adjusted up to Turkey's condition. The final version of the questionnaire was tested by a pilot study with 12 freight forwarders. Wordings of 3 variables in the questionnaire was slightly changed and clarified in order to increase understandability. The questionnaire consists of two sections. In the first section of the questionnaire, profile questions of forwarders were asked to respondents including their experience and the ports they work with. The second part includes 35 port selection variables for freight forwarders.

Interval scale was used for the questionnaire to weigh the importance of each criterion for port selection. In the interval scale, 1 means "not at all important" and 5 means "very important".

The sample used in the study was obtained from the population of freight forwarders in Turkey to determine port selection criteria for users in contestable hinterlands. Freight forwarders were chosen as respondents of the survey as they act as an intermediary between shippers and shipping. The member list of International Association of Forwarding and Logistics Service Providers (UTIKAD) was used to determine the population and sampling of the study. At the time of conducting the study, the total number of freight forwarders who are the member of UTİKAD was determined as 408 including both logistics service providers and sea transportation professionals. However, 132 of them offer sea transportation services. Totally 74 usable questionnaires were received from 52 companies. It means that the total response rate was $39.4 \%$.

Total response number may seem not satisfactory for implementing confirmatory factor analysis but it is a fact that the number of respondents is limited in the port and shipping industry. Besides, the number of forwarding companies which work for the shipments from these cities are limited. Also the number of respondants in other studies that apply CFA is limited too. For instance, Chang et al. [33] also implemented confirmatory factor analysis for 21 items with only 28 responses. Lu [34] also applied exploratory factor analysis for 30 items and carried out structural equation modelling with total 87 responses.

\section{Findings}

Structural validity of the model in this research was ensured through three types of validity that include content validity, convergent validity, and discriminant validity. Content validity was ensured through including variables in relative literature and consulting these variables to experienced practitioners and academicians in shipping and port industry to assess the appropriateness of them for measuring port selection criteria. The variables were also assessed with 3 academicians who have expertise on shipping and port business. Confirmatory factor analysis (CFA) was performed in order to ensure convergent validity and discriminant validity.

CFA was implemented to ensure that grouping of 35 variables under 7 main constructs were valid. The 35 variables were reduced to 32 to enhance model fit by deleting such three variables: "Relation dated to back between a port and your company", "Duration of average container loading/unloading", "Distance between port and airport". Then, the error terms that show high correlations in the same constructs was covariated as suggested by [35] in order to improve the model fit. Convergent and discriminant validity were tested through model fit indices. Factor loadings and construct correlations and average variance extracted and construct reliability indicators were presented in the below figure and tables. 


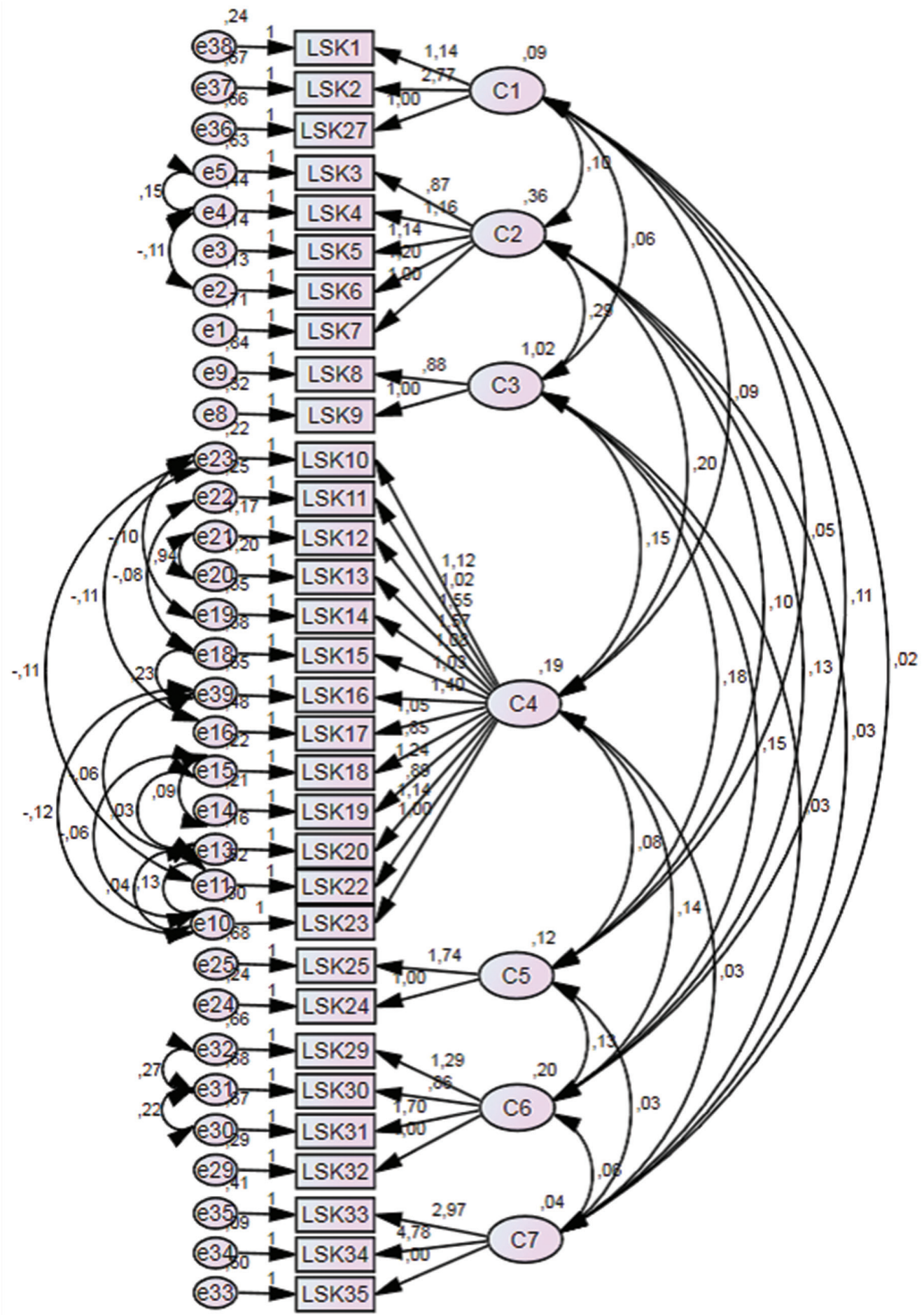

Figure 1. Results of Confirmatory Factor Analysis 
CFA presents a range of information to test the convergent validity. Table 2 presents the factor loadings. The lowest loading is the 0.85 which links the "Service Quality of Port" (C4) to the "Performance of Port about Cargo Loss and Damage" (LKS18). The other loadings are even higher than 0.85 . They are all higher than 0,7 .

Table 2. Standardized Factor Loadings

\begin{tabular}{|c|c|c|}
\hline Constructs & Factors & \\
\hline \multirow{3}{*}{$\begin{array}{l}\text { Port Location and Hinterland } \\
\text { Connections (C1) }\end{array}$} & Port-Road Connection (LSK1) & 1,14 \\
\hline & Port-Railway Connection (LSK2) & 2,77 \\
\hline & Distance of Port to Cargo Origin and Destination (LSK27) & 1,00 \\
\hline \multirow{5}{*}{$\begin{array}{l}\text { Port Physical and Technical } \\
\text { Infrastructure and Superstructure } \\
\text { (C2) }\end{array}$} & Size of Port Warehousing Area (LSK3) & 0,87 \\
\hline & Information Technologies Used at Port (LSK4) & 1,16 \\
\hline & Number of Port Equipment (LSK5) & 1,14 \\
\hline & Quality and Technology of Port Equipment (LSK6) & 1,20 \\
\hline & Reefer Cargo Warehousing Capacity of Port (LSK7) & 1,00 \\
\hline \multirow{2}{*}{$\begin{array}{l}\text { Port Management and } \\
\text { Administration (C3) }\end{array}$} & Port Management Type (LSK8) & 0,88 \\
\hline & Feature of Port Operating Company (LSK9) & 1,00 \\
\hline \multirow{13}{*}{ Port Service Quality (C4) } & Value-added Services offered at Port (LSK10) & 1,12 \\
\hline & Reliability of Services offered by Port (LSK11) & 1,02 \\
\hline & Corporate Social Responsibility of Port (LSK12) & 1,55 \\
\hline & Green Port Applications of Port (LSK13) & 1,57 \\
\hline & Logistics Services Provided by Port (LSK14) & 1,08 \\
\hline & $\begin{array}{l}\text { Flexibility of Port for Specific Requirement of Customers } \\
\text { (LSK15) }\end{array}$ & 1,09 \\
\hline & Customized Services (LSK16) & 1,40 \\
\hline & Informing Shippers about Shipment (LSK17) & 1,05 \\
\hline & $\begin{array}{l}\text { Performance of Port About Cargo Loss and Damage } \\
\text { (LSK18) }\end{array}$ & 0,85 \\
\hline & Safety of Port (LSK19) & 1,24 \\
\hline & Quick Response to Users Problem (LSK20) & 0,88 \\
\hline & Attitude and Behavior of Port Personal (LSK22) & 1,14 \\
\hline & $\begin{array}{l}\text { Experience and Ability and Competence of Port Personal } \\
\text { (LSK23) }\end{array}$ & 1,00 \\
\hline \multirow{2}{*}{$\begin{array}{l}\text { Port Efficiency and Productivity } \\
\text { (C5) }\end{array}$} & Congestion at Port (LSK25) & 1,74 \\
\hline & Total Turnaround Time (LSK24) & 1,00 \\
\hline \multirow{4}{*}{ Port Tariff and Costs (C6) } & Total Port Tariff and Cost (LSK29) & 1,29 \\
\hline & Flexibility of Port in Pricing (LSK30) & 0,86 \\
\hline & Ease of Payment for Customers (LSK31) & 1,70 \\
\hline & Total Logistics Cost incurred due to Port Choice (LSK32) & 2,00 \\
\hline \multirow{3}{*}{$\begin{array}{l}\text { Number and Frequency of } \\
\text { Shipping Lines Calling at Port (C7) }\end{array}$} & Number of Container Lines Calling the Port (LSK33) & 2,97 \\
\hline & Frequency of Sailings (LSK34) & 4,78 \\
\hline & Total Transit Time for Cargo (LSK35) & 1,00 \\
\hline
\end{tabular}

(LSK refers to port selection criteria) 
The Average Variance Extracted estimates were presented in Table 3 . The AVE estimates range between 0.47 and 0.55. The three of the AVE values were slightly lower than the threshold value of 0,50 indicated by [33]: 0.47 for "Port Location and Hinterland Connections" (C1) ; 0.47 for "Port Efficiency and Productivity" (C5) and 0.48 for "Port Management and Administration" (C3). The others were higher than the threshold value of 0.50 .

Construct reliability values range between 0,65 and 0,78 . The threshold value for construct reliability is the 0,7 [35] Table 4 shows the construct reliability values. The construct reliability values of the three of the constructs were slightly lower than this threshold value. Those include: 0,68 for "Port Location and Hinterland Connections" (C1); 0,65 for "Port Management and Administration" (C3) and 0,69 for "Port Efficiency and Productivity" (C5). The other values were higher than the threshold of 0,7 .
Considering the convergent validity measures altogether, the values confirm the model ensuring the convergent validity. All factor loadings exceed the threshold value of 0.7. In conclusion, all values of the item used for testing the convergent validity provides evidence that convergent validity of the model relatively is ensured.

To examine the discriminant validity, it is needed to check the correlations between constructs. According to [35] for establishing discriminant validity, the values of AVE of the constructs need to be compared with the construct correlations and the construct correlations should not exceed the AVE values. Construct correlation matrix presented in Table 3 and the AVE values were presented in Table 4. All the estimated values of AVE presented in Table 4 were higher than the construct correlation values presented in Table 3. Thus, this can be interpreted as the discriminant validity is ensured.

The model fit indices indicate the

Table 3. Construct Correlation Matrix

\begin{tabular}{|c|c|c|c|c|c|c|c|}
\hline & C1 & C2 & C3 & C4 & C5 & C6 & C7 \\
\hline C1 & 1,00 & 0,10 & 0,06 & 0,09 & 0,05 & 0,11 & 0,02 \\
\hline C2 & & 1,00 & 0,29 & 0,20 & 0,10 & 0,13 & 0,03 \\
\hline C3 & & & 1,00 & 0,15 & 0,18 & 0,15 & 0,03 \\
\hline C4 & & & & 1,00 & 0,08 & 0,14 & 0,03 \\
\hline C5 & & & & & 1,00 & 0,13 & 0,03 \\
\hline C6 & & & & & & 1,00 & 0,06 \\
\hline C7 & & & & & & & 1,00 \\
\hline
\end{tabular}

Table 4. Average Variance Extracted and Construct Reliability

\begin{tabular}{|c|c|c|c|c|c|c|c|}
\hline & C1 & C2 & C3 & C4 & C5 & C6 & C7 \\
\hline $\begin{array}{c}\text { Average Variance } \\
\text { Extracted }\end{array}$ & 0,47 & 0,53 & 0,48 & 0,54 & 0,47 & 0,55 & 0,52 \\
\hline $\begin{array}{c}\text { Construct } \\
\text { Reliability }\end{array}$ & 0,68 & 0,71 & 0,65 & 0,78 & 0,69 & 0,74 & 0,72 \\
\hline
\end{tabular}

Table 5. Summary of Modal Fit Indices of Confirmatory Factor Analysis

\begin{tabular}{|c|c|c|c|c|c|c|}
\hline & $\mathbf{X 2} / \mathbf{d f}$ & CFI & TLI & GFI & SRMR & RMSEA \\
\hline $\begin{array}{c}\text { Reference } \\
\text { Index [10] }\end{array}$ & $<3 / 1$ & $>0.90$ & $>0.90$ & $>0.90$ & $\begin{array}{c}<0,5 \\
\text { (acceptable } \\
\text { up to 0.8) }\end{array}$ & $\begin{array}{c}<0,5 \\
\text { (acceptable } \\
\text { up to 0.8) }\end{array}$ \\
\hline Index of Results & 1,532 & 0.91 & 0.84 & 0.87 & 0.71 & 0.75 \\
\hline
\end{tabular}


fitness level of the model. Table 5 shows the model fit indices of CFA. X2/df is within the threshold. CFI is just little higher than the threshold with the value of 0.91 . TLI is slightly below the threshold of 0.90 with a value of 0.84 and CFI is also slightly under the threshold of 0.90 with a value of 0.87 . The SRMR value is in the range of acceptable level with a value of 0.71 . RMSEA value is also in the acceptable range, with a value of 0.75 . In overall, values of model fit indices are in the ranges of acceptable levels that show the model fit is relatively well.

In order to test the internal reliability of the study, Cronbach's alpha was performed. The Cronbach's alpha value of this study is 0.917 over 32 items; thus the scale can be defined as reliable.

However only the Cronbach's alpha value is not enough to explain reliability, therefore each question was individually to be investigated in terms of their support to reliability to make an accurate evaluation. A significant change does not occur even if any item is deleted. However, if some questions were deleted the reliability would dreamy be decreasing. Only "Port Administration Type" and "Distance of Port to Cargo Origin and Destination" face 0.001 positive effects on reliability.

\subsection{Profile of Respondents}

The profile questions of the study include industrial experience and experience in the company of the respondents. In addition to this, ports used by the freight forwarders are also involved in the profile questions.

Overall experience is important to measure the perception of respondents on port selection criteria. $54.7 \%$ of the respondents have experience of between 3-9 years in the maritime transport industry. $16 \%$ of the respondents have experience of 10 years and more; and $29.3 \%$ of respondents have experience of between 0-2 years in the maritime transport industry.

The respondents were also asked how long they have been working in their company. 50.7 percent of the respondents have experience of between 0-2 years in their company. $38.7 \%$ of the respondents have experience of between 3-9 years, and $10.6 \%$ of respondents have experience of 10 years and more.

The port selection by the freight forwarders for the cargo shipments from/ to Ankara (Green city), Eskișehir (Blue city), Kütahya (Gray city) consists of 10 ports and others. It includes 3 ports from İzmir port region, 3 ports from Marmara port region,

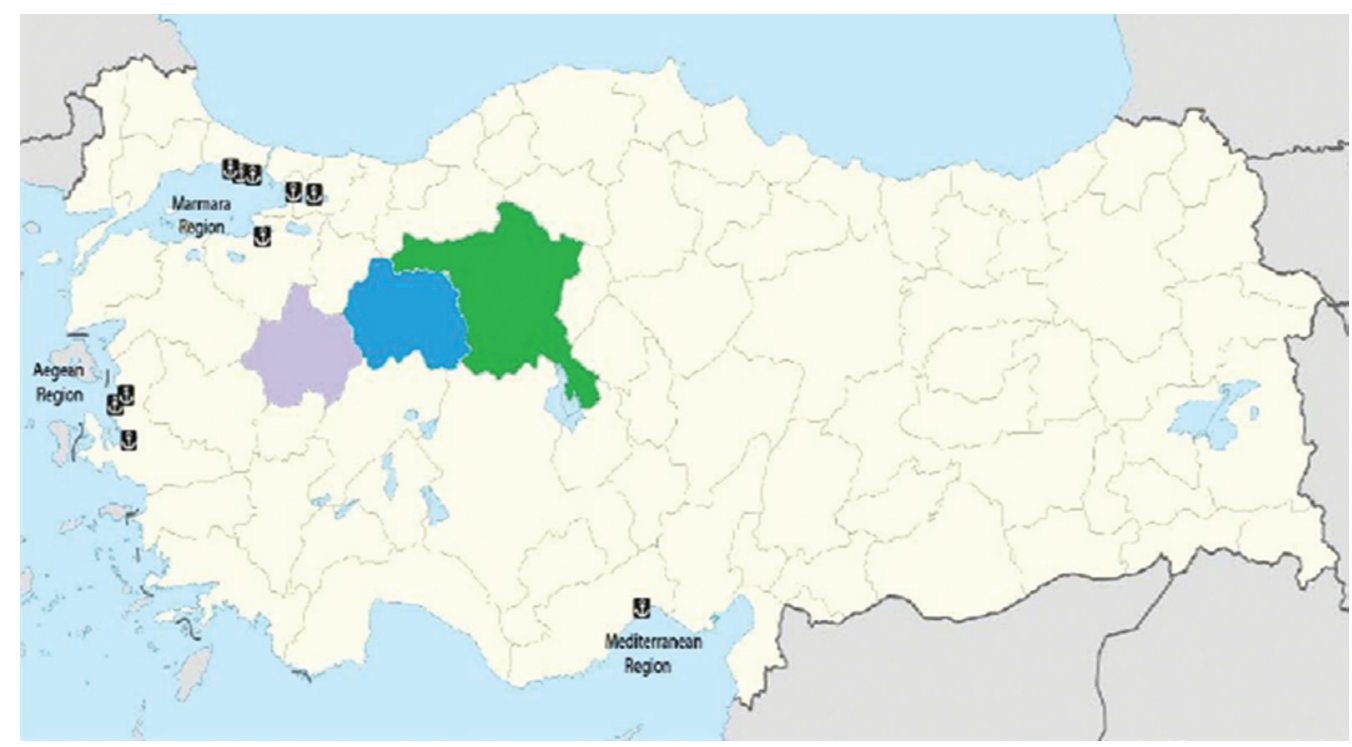

Figure 2. Illustration of Selected Hinterlands and Ports on Map 
2 ports from İzmit port region, 1 port from South Marmara region, and 1 port from Mediterranean region. The results show that the majority of participants use the port of İzmir Alsancak with 94.6 percent. Port of TCEEGE and Port of Mersin are also selected by nearly 83 percent of the respondents. Except "other ports" option, Mardaş Port was selected at lowest degree by respondents with 58 percent.

\subsection{Variance Analysis}

According to Multiple Comparison Data which is obtained from One-Way ANOVA test of this study, significant differences are observed between independent variables. That is to say, it has been achieved that there is a significant difference between the industrial experience of groups in considering the importance of the port selection variables. Similar distinctions have been found for other independent variables of the study which is "experience of respondents in their company".

\subsection{Descriptive Statistics of the Study}

According to Table 2, mean scores and standard deviations scores were sequentially extracted from the highest value to the lowest value. "Congestion at port" has been found as the most important port selection criteria by freight forwarders (4.74). The other two important factors are "road connection of port" and "quick response to users' problem" with the value of 4.72. "Performance of port about cargo loss and damage" follows them with 4.68; and the last but not the least "reliability of services given by port" with 4.62 mean value. On the other hand, lowest ranking is "corporate social responsibility" with 2.93 ; and "feature of port operating company" has also been given second least significance with 3.01 average. The third lowest value has been given for "green port applications" with 3.45. A slightly higher consideration has been given for "railway connection of port" with 3.55; and "reefer cargo warehousing capacity of port" has been selected with 3.77 mean value.

The seven main constructs of the port selection variables have individually been dealt with. These constructs have been chosen in average as follows: "Port location and hinterland connection" with 4.13 mean value; "port physical and technical infrastructure and superstructure" with 4.15 mean value; "port management and administration" with 3.39 mean value; "service quality of port" with 4.26 mean value; "port efficiency and productivity" with 4.50 mean value; "port tariffs and costs" with 4.29 mean value; and "Number and frequency of shipping lines calling at port" with 4.33 mean value.

\section{Discussion and Conclusion}

Ports are strategic points in global supply chain, and they directly affect both shippers and shipping service providers; because port service level is an important determinant in reducing time and cost and in increasing quality. By courtesy of port privatization and intense land transportation investments contestability of hinterlands and competitive level of ports are improving. Therefore this study focused on selection criteria for port users in contestable hinterlands, and a model was developed to measure these criteria.

A confirmatory factor analysis was performed to ensure the validity of the model and 3 variables were deleted from 35 variables to increase model fit. In the end, a model including 7 main constructs comprising 32 criteria was developed for port selection criteria in contestable hinterlands. These constructs are port efficiency and productivity, number and frequency of shipping lines calling at the port, port tariff and costs, service quality of the port, port physical and technical infrastructure and superstructure, port location and hinterland connection and port management and administration.

In the study, congestion at the port, road connection of port; quick response to users' problems; performance of port about cargo 
Table 6. Descriptive Statistics of Port Selection Variables

\begin{tabular}{|c|c|c|c|}
\hline Port Selection Variables & $\mathbf{N}$ & Mean & Std. Deviation \\
\hline Congestion at Port & 74 & 4,74 & 0,598 \\
\hline Road Connection of Port & 74 & 4,72 & 0,609 \\
\hline Quick Response to Users' Problem & 74 & 4,72 & 0,562 \\
\hline $\begin{array}{l}\text { Performance of Port About Cargo Loss and } \\
\text { Damage }\end{array}$ & 74 & 4,68 & 0,599 \\
\hline Reliability of Services Given by Port & 74 & 4,62 & 0,676 \\
\hline Safety of Port & 74 & 4,61 & 0,718 \\
\hline $\begin{array}{l}\text { Experience and Ability and Competence of } \\
\text { Port Personal }\end{array}$ & 74 & 4,59 & 0,701 \\
\hline $\begin{array}{l}\text { Total Logistics Cost incurred due to Port } \\
\text { Choice }\end{array}$ & 74 & 4,51 & 0,707 \\
\hline Logistics Services Given at Port & 74 & 4,47 & 0,763 \\
\hline Value added Services Given at Port & 74 & 4,46 & 0,686 \\
\hline Quality and Technology of Port Equipment & 74 & 4,43 & 0,812 \\
\hline $\begin{array}{l}\text { Flexibility of Port for Specific Requirement of } \\
\text { Customers }\end{array}$ & 74 & 4,42 & 0,776 \\
\hline Total Transit Time for Cargo & 74 & 4,38 & 0,735 \\
\hline Number of Port Equipment & 74 & 4,36 & 0,786 \\
\hline Total Port Tariff and Cost & 74 & 4,36 & 1,001 \\
\hline Flexibility of Port in Pricing & 74 & 4,31 & 0,92 \\
\hline Frequency of Sailings & 74 & 4,31 & 0,95 \\
\hline Number of Container Lines Calling the Port & 74 & 4,3 & 0,856 \\
\hline $\begin{array}{l}\text { Information Provided for Shipment of } \\
\text { Shippers }\end{array}$ & 74 & 4,28 & 0,836 \\
\hline Total Turnaround Time & 74 & 4,27 & 1,024 \\
\hline $\begin{array}{l}\text { Distance of Port to Cargo Origin and } \\
\text { Destination }\end{array}$ & 74 & 4,2 & 0,876 \\
\hline Customized Services for Customers & 74 & 4,15 & 0,975 \\
\hline Information Technologies Used at Port & 74 & 4,09 & 0,968 \\
\hline Attitude and Behaviour of Port Personal & 74 & 4,05 & 0,949 \\
\hline Size of Warehousing Area at Port & 74 & 4,01 & 0,958 \\
\hline Ease of Payment for Customers & 74 & 4 & 1,123 \\
\hline Port Management Type & 74 & 3,78 & 1,285 \\
\hline Reefer Cargo Warehousing Capacity of Port & 74 & 3,77 & 1,041 \\
\hline Railway Connection of Port & 74 & 3,55 & 1,184 \\
\hline Green Port Applications of Port & 74 & 3,45 & 1,305 \\
\hline Feature of Port Operating Company & 74 & 3,01 & 1,164 \\
\hline Corporate Social Responsibility of Port & 74 & 2,93 & 1,286 \\
\hline
\end{tabular}


loss and damage; and reliability of services given by port were selected as top 5 most important criteria. The five least important criteria were found as; reefer cargo warehousing capacity of the port; railway connection of port; green port applications; the feature of port operating company; and corporate social responsibility of port. Comparing to other forwarder based port selection studies, the results of the study show both similarities and dissimilarities. An important point of this study is that congestion at the port was determined as the most important criterion for port selection. This criterion might be chosen as the most important because port users suffered from extreme port congestion at the land side and sea side, and delays in the past at some ports such as Port of İzmir.

The top five most important criteria show that users are quite concerned about delays, reliability of service, damages and problem handling capabilities of port employees. The increasing importance of supply chain performance and advanced supply chain applications such as just-in-time require extreme reliability on timeliness, services, and delivery without damage and loss. This explains why these top 5 criteria, especially congestion at the port, quick response to users' problem, the reliability of services and cargo loss and damage performance, were chosen as the most important ones. Green port applications and corporate social responsibility were found as the two of least important criteria. This implies the lack of attention of companies regarding environmental and social concerns when selecting a port.

In terms of the constructs, the most important factor is port efficiency and productivity. Efficiency is also found to be an important criterion in other port selection studies with shipping line and shipper perspective. For instance, Tongzon and Sawant [36] investigated port selection in shipping line perspective and they found efficiency as the most important criterion just as we found in this study. Number and frequency of shipping lines is found to be the second most important factor in this study. The high importance level of this factor is compatible with the study of De Langen [4], who found quality of shipping services (frequency) as the most important criterion in the perspective of forwarders. This suggests that forwarders think that port selection in contestable hinterlands is not carried out only based on pure port and hinterland related matters but also shipping services given at port. In fact, port users give importance to total transit time, directness of sailing and freight rate from the loading port to discharging port. All of them are affected by the number and frequency of shipping lines at a port. Thus, total transit time and total transit costs are actually quite influential in the port selection of freight forwarders. In other words, port users in contestable hinterlands select shipping service considering the final destination of their cargo.

Comparing the results of this study (that investigates the port selection in contestable hinterlands) and other port selection papers, both similarities and dissimilarities are observed. In terms of similarities, the variables that Slack [37] used are very similar to our study number of sailings, freight rates, congestion and intermodal links). In paralel to our study Tongzon [38] also found frequency of ship visit, port efficiency and port charges as important port selection variables. Regarding these variables port selection in contestable hinterlands does not differ a lot from other port selection studies. However, there are also some distinctions between port choice of captive and contestable hinterlands. For instance, port location was found the second least important consturct in our paper, on the other hand port location is an important determinant of other port selection studies $[38,39,40,41,42]$. This distinction is not surprising because the distance between origin of cargo and different ports in contestable hinterlands is almost equal in terms of time and/or cost. 
Port managers should bear in mind that expectations of port users in contestable hinterlands are quite demanding. Considering the recent developments in logistics systems, users demand more reliable, on time and safe services with competitive prices. Users expect port managers to provide solutions for their problems. Port managers should consider that port selection decisions are not made merely based on the services given by them. The decision is also affected by hinterland connections and shipping services of a port. Thus, port managers should also attract shipping lines so that port users located in contestable hinterlands can be offered more frequent shipping services. Moreover, efficiency and charges are noted as the important attractiveness for port users.

There are several limitations in this study. First, this study was focused on merely container terminals which are faced with competition in contestable hinterlands. Second, the study was applied only on freight forwarders who are members of UTIKKAD (Association of International Forwarding and Logistics Service Providers). Third, only a specific region was selected as a contestable hinterland to implement the survey of this study. Finally, this study did not consider the competition between container terminals in terms of transshipment cargoes. Further studies may include shippers and container lines to demonstrate perceptional differences between different port users. Moreover, several contestable hinterlands can also be investigated to reveal if any difference exists between the users in different hinterlands regarding port selection criteria.

\section{References}

[1] Robinson, R., 2002, Ports as elements in value-driven chain systems: The new paradigm. Maritime Policy and Management 29: 241-255.

[2] Notteboom, T, 2004, Inter-firm collaboration, learning and networks: An integrated approach. London:
Routledge.

[3] Baird, A. J., 2002, Privatization trends at the world's top-100 container ports. Maritime Policy and Management, 29 (3), 271-284.

[4] De Langen, P. W., 2007, Port competition and selection in contestable hinterlands: The case of Austria. European Journal of Transport and Infrastructure Research, 7 (1): 1-14.

[5] Tongzon, J. L., 2009, Port choice and freight forwarders, Transportation Research Part E, 45 (2009): 186-195.

[6] Bichou, K., 2009, Port Operations, Planning and Logistics. London: Informa.

[7] Ng, A. K. Y., 2009, Competitiveness of short sea shipping and the role of port: The case of North Europe. Maritime Policy and Management, 36 (4): 337352.

[8] Kim, J. K., 2014, Port user typology and representations of port choice behavior: Q-methodological study, Maritime Economics and Logistics, 16 (2): 165-166.

[9] Cullinane, K. and Talley, W. K., 2006, Port economics (Vol. 16). Amsterdam: Elsevier.

[10] Meersman, H., Van de Voorde, E.and Vanelslander, T., 2010, Port competition revisited. Journal of Pediatric, Maternal and Family HealthChiropractic, 55 (2): 210.

[11] Talley, W. K., 2009, Port Economics. New York: Routledge.

[12] Hesse, M. and Rodrigue, J. P., 2004, The transport geography of logistics and freight distribution. Journal of Transport Geography, 12: 171-184.

[13] Zondag, B., Bucci, P., Gützkow, P. and De Jong, G., 2010, Port competition modeling including maritime, port, and hinterland characteristics. Maritime Policy and Management, 37 (3): 179-194.

[14] Van Der Horst, M. R. and De Langen, P. W., 2008, Coordination in hinterland 
transport chains: A major challenge for the seaport community. Maritime Economics and Logistics, 10 (1): 108129.

[15] Rodrigue, J. P. and Notteboom, T., 2007, Re-assessing port-hinterland relationships in the context of global commodity chains. In: Ports, Cities, and Global Supply Chains, edited by Wang. J, Olivier, D., Notteboom, T. and Slack, B. London: Ashgate, pp.51-66.

[16] Jafari, H. and Khosheghbal, B., 2013, Studying seaport's hinterlandforeland concepts and the effective factors on their development. International Research Journal of Applied and Basic Sciences, ISSN, 1039-1046.

[17] Rodrigue, J. P. and Notteboom, T., 2006, Challenges in the maritimeland interface: Port hinterlands and regionalization. The Master Development Plan For Port Logistics Parks In Korea; Seoul: Ministry of Maritime Affairs and Fisheries: 333363.

[18] OECD, 2008. Port competition and hinterland connections, Paris: OECD/ ITF.

[19] De Langen, P. W. and Chouly, A., 2004, Hinterland access regimes in seaports. European Journal of Transport and Infrastructure Research, 4: 361-380.

[20] Notteboom, T., 2002, Consolidation and contestability in the European container handling industry. Maritime Policy \& Management 29 (3), 257269.

[21] Fraser, D. and Notteboom, T., 2012, Gateway and hinterland dynamics: The case of the Southern African container seaport system. African Journal of Business Management, 6 (44): 10807-10825.

[22] Cullinane, K. and Wang, Y., 2009, A Capacity-Based Measure of Container Port Accessibility. International Journal of Logistics: Research and Applications, 12(2): 103-117.
[23] Van Der Horst, M. R. and Van Der Lugt, L. M., 2011, Coordination mechanisms in improving hinterland accessibility: Empirical analysis in the port of Rotterdam. Maritime Policy and Management, 38 (4): 415-435.

[24] Notteboom T, 1997, Concentration and load center development in the European container port system. Journal of Transport Geography, 5 (2): 99-115.

[25] Vermeiren, T. and Macharis, C., 2016, Intermodal land transportation system and port choice, an analysis of stated choice among shippersin the Rhine-Scheldt delta, Maritime Policy and Management, 43: 2-3.

[26] Saeed, N. and Aaby, B. C., 2013, An analysis of factors contributing as selection criteria for users of European container terminals. TRB 2013 Annual Meeting.

[27] Nazemzadeh, M. and Vanelslander, T., 2015, The container transport system: Selection criteria and business attractiveness for NorthEuropean ports, Maritime Economics and Logistics, 17 (2): 222.

[28] Lam, J. S. L. and Dai, J., 2012, A decision support system for port selection. Transportation Planning and Technology, 35 (4): 509-524.

[29] Ng, A. S. F., Sun, D., and Bhattacharjya, J., 2013, Port choice of shipping lines and shippers in Australia, Asian Geographer, 30 (2): 151-155.

[30] Yap, W. Y. and Notteboom, T., 2011, Dynamics of liner shipping service scheduling and their impact on container port competition, Maritime Policy and Management, 38 (5): 475483.

[31] Wiegmans, B. W., Van Der Hoest, A. and Notteboom, T., 2008, Port and terminal selection by deep-sea container operators, Maritime Policy and Management, 35 (6): 526-531.

[32] Kim, Y. S., Yur, Y. S. and Shin, C. H., 2009, Review of theoretical aspects on 
the studies of port selection criteria. Journal of Korean Navigation and Port Research, 33 (2): 135-141.

[33] Chang, Y. T., Lee, S. Y. and Tongzon, J. L., 2008, Port selection factors by shipping lines: Different perspectives between trunk liners and feeder service providers, Marine Policy, 32 (6): 877-885.

[34] Lu, C. S., 2003, The impact of carrier service attributes on shipper-carrier partnering relationships: A shipper's perpective, Transportation Research Part E, 39 (6): 399-415.

[35] Hair, J. F., Black, W. C., Babin, B. J., Anderson, R. E. and Tatham, R. L., 2010, Multivariate data analysis (Vol. 7) (Upper Saddle River, NJ: Pearson Prentice Hall).

[36] Tongzon, J. L. and Sawant, L., 2007, Port choice in a competitive environment: From the shipping lines' perspective, Applied Economics, 39: 477-492.

[37] Slack, B., 1985, Containerization, interport competition, and port selection, Maritime Policy and Management, 12 (4): 293-303.

[38] Tongzon, J. L., 2009, Port choice and freight forwarders, Transportation Research Part E, 45 (1): 186-195.

[39] Malchow, M. B., 2001, An analysis of port selection, Institute of Transportation Studies University of California, PhD Thesis.

[40] Malchow, M. B. and Kanafani, A., 2004, A disaggregate analysis of port selection, Transportation Research Part E, 40 (4): 317-337.

[41] Song, D. and Yeo, K., 2004, Acompetitive analysis of Chinese container ports using analytic hierarchy process, Maritime Economics and Logistics, 6: 34-52.

[42] Mangan, J., Lalwani, C. and Gardnder, B., 2002, Modeling port/ferry choice in ro-ro freight transportation, International Journal of Transport Management, 1 (1): 15-28. 